\title{
Effect of Bacteriocin on Soft Cheese
}

\author{
Silvia M. Zaky ${ }^{1}$ and Wafaa A. Mahmoud ${ }^{1}$
}

\begin{abstract}
This study was carried out to produce soft cheese Ricotta at various concentrations $(0.1,0.2,0.3 \mathrm{gm} . / \mathrm{kg}$ buffalo milk ) of nisin as bio-preservative to extend the shelf life of cheese. The effect of nisin on physo-chemical, rheological, microbial and sensory evaluation were studied. Addition of nisin reduced the development of acidity and microbial count during storage periods. The sensory properties of Ricotta cheese improved with the addition of 0.2 and $0.3 \mathrm{gm}$. of nisin than $0.1 \mathrm{gm}$ and control samples during storage periods. The cheese samples fortified with nisin gained higher scores than control samples. Addition of 0.2 and $0.3 \mathrm{gm}$. of nisin to increase the shelf life and used as a natural food preservative of Ricotta cheese can be recommended without any adverse effect on the properties of the obtained product.
\end{abstract}

Keywords: Soft cheese - Nisin - Self-life

\section{INTRODUCTION}

The request for an extended shelf-life of food products is becoming essential and a pressing issue. On the other hand, spores and thermophilic bacteria resist the production process and, with the extension of shelflife, enhance spoilage events and pose issues regarding the safety of the product. Thus the extension of shelf-life remains a challenging goal (Postollec et al.,2012).

The peptide nisin is a class bacteriocin produced by some strain of lacococcus lactis subsp lactis(Klaenhammer, 1993). Nisin has been recognized as a safe food preservative by the hoint Food and Agriculture organization and World Health Organisation (FAOIWHO).

Nisin has been approved world-wide for use as a natural food preservative and its main commercial application, under the trade name Nisaplin ${ }^{\circledR}$ (Aplin \& Barrett Ltd, Trowbridge, UK), is in processed cheese to inhibit the outgrowth of spores (Delves-Broughton 1990). Adding of nisin to milk in production of soft, white, fresh cheeses made without starter culture (normally acidified or coagulated with rennet), such as Ricotta, panir and Latin-American cheeses queso blanco and queso fresco (for guide to cheese types see Campbell 1- Platt 1987), was important for control contamination with the pathogen Listera. monocytogenes and extend the shelf-life of the product. It has been studied that L. Lactis subsp. lactis produces nisin with an antimicrobial activity against closely related Gram-positive bacterial strains, food- spoilage and food borne pathogens such as Bacillus cereus, B. ther-mosphacta, Clostridium botulinum, Staphylococcus. aureus, Listeria innocua and Listeria monocytogenes ( Hwanhlem et al., 2013). The spoilage and pathogenic microorganism growth and survival depends on external factors associated with production and storage conditions, but also on intrinsic factors such as the composition of the microbial community (Ledenbach and Marshall, 2009).

Production of bacteriocins enhances the ability of Lactic acid bacteria (LAB) to control the growth of pathogens and food spoilage bacteria in food products ( Dal Bello et al., 2012) and makes them of particular interest to food industry offering natural alternatives for chemical additives to improve the safety and quality of food products. Bacteriocins is a safe food biopreservatives and can be degraded by gastrointestinal proteases (Jeevaratnam, et al.2005).

Ricotta cheese is a soft cheese, made mainly from sheep or goat milk, or a mixture of both, but also from cow and buffalo milk (Mucchetti et al., 2002).

\section{MATERIALS AND METHODS}

\section{1- Manufacture of cheese}

Ricotta cheese was made according to the method described by Modler (1988). Four equal portion of buffalo milk were heated at $90^{\circ} \mathrm{C}$, nisin were added individually at ratios of $0.1,0.2,0.3 \mathrm{~g} / \mathrm{Kg}$ buffalo milk to different portions of the heated milk and mixed well . The milk supplemented with nisin ( Nisaplin ${ }^{\circledR}$, material no.114374) was inoculated with lactic acid to induce coagulation of Ricotta cheese and storage of cheese for 28 days at $5^{\circ} \mathrm{C} \pm 2{ }^{\circ} \mathrm{C}$ and compared the results with control cheese .

\section{2- Cheese analysis}

The $\mathrm{pH}$ of cheese, the titrimetric determination of acidity, moisture, fat, total nitrogen and soluble nitrogen was accomplished according to the AOAC(1991).

\section{3- Microbiological analysis}

All samples of cheese were examined for total bacterial count (TBC) and proteolytic bacterial count

DOI: 10.21608/ASEJAIQJSAE.2019.40785

Faculty of Agriculture. Alex.Univ., Food Technology Research Institute(FTRI)

Received May 28, 2019, Accepted June 30, 2019 
according to American public health association (APHA, 1992).

4- Sensory evaluation scores of cheese

Organoleptic evaluation was carried out according to the scheme of Bodyfelt and Potter (2009). Ricotta cheese samples was subjected to Organoleptic analysis by 10 staff members of Food Science Department (Fac.of Agric., Alex. Univ.) The sensory attributes evaluated were : The flavor (1-10 points), body \& texture (1-5 points), and appearance and color (1-5 points).

5- Rheological properties :

Rheological properties of cheese: The texture properties of cheese samples were evaluated using texture analyzer Lab pro ( FTC TMS-pro, USA ) in Brookfield Engineering Labs, Inc. Control and experimental cheese samples were taken from fresh cheeses and 28 days of storage, then were measured immediately. Cheese sample size was $30 \mathrm{~mm}$ of diameter and $20 \mathrm{~mm}$ of high. Speed was $1 \mathrm{~mm} / \mathrm{s}$ and 10 $\mathrm{mm}$ was the distance of penetration. Samples were allowed to stand at ambient temperature for at least 20 min prior testing. The probe used was TA15-450C perplex cone. Data were collected on computer and the texture profile parameters were calculated from LFRA texture analyzer and computer interface. The following texture profile parameters were obtained and calculated as describe by Bourne (1978). The compressive force (g) recorded at maximum compressive during in the first bite as a measure of Hardness) The ratio of the positive force area under the curve during the second compression (bite) to that during the first compression (a2/a1) as a measure of cohesiveness). The height (mm) to which the sample recovered during the time that clasped between the end of the first bite the start of the second bite, as a measure of Springiness.

\section{RESULTS AND DISCUSSION}

\section{Chemical composition of Ricotta cheese with nisin}

Table (1) shows the chemical composition of Ricotta cheese during storage periods at $5^{\circ} \mathrm{C} \pm 2{ }^{\circ} \mathrm{C}$ for 14 and 28 days. Generally, acidity, fat, total solids and soluble nitrogen content increased while, $\mathrm{pH}$ and moisture decreased during storage periods. Increasing in acidity and decreasing in $\mathrm{pH}$, moisture was less in cheese with nisin than control cheese. Acidity increased from 0.56 to 0.97 in control cheese while, cheese with nisin, acidity increased from 0.55 to $0.80,0.57$ to 0.76 and 0.54 to 0.70 in treatment $\mathrm{B}, \mathrm{C}$ and $\mathrm{D}$ respectively. Similar results were reported by Olmedo et al.,(2013).

Table 1.The chemical composition of Ricotta cheese during storage periods

\begin{tabular}{cccccc}
\hline Treatments & $\begin{array}{c}\text { Storage } \\
\text { Period (days) }\end{array}$ & A & B & C & D \\
\hline & Fresh & 0.56 & 0.55 & 0.57 & 0.54 \\
Acidity \% & $\mathbf{1 4}$ & 0.82 & 0.71 & 0.66 & 0.61 \\
& $\mathbf{2 8}$ & 0.97 & 0.80 & 0.76 & 0.70 \\
pH value & Fresh & 5.91 & 5.97 & 5.94 & 5.96 \\
& $\mathbf{1 4}$ & 5.70 & 5.74 & 5.78 & 5.81 \\
& $\mathbf{2 8}$ & 5.43 & 5.51 & 5.57 & 5.62 \\
Moisture \% & Fresh & 59.623 & 59.522 & 59.233 & 59.462 \\
& $\mathbf{1 4}$ & 58.671 & 58.503 & 57.882 & 58.337 \\
& $\mathbf{2 8}$ & 57.923 & 57.628 & 56.765 & 57.279 \\
TS\% & Fresh & 40.377 & 40.478 & 40.767 & 40.538 \\
& $\mathbf{1 4}$ & 41.329 & 41.497 & 42.118 & 41.663 \\
& $\mathbf{2 8}$ & 42.077 & 42.372 & 43.235 & 42.721 \\
Fat \% & Fresh & 19 & 19.1 & 19.3 & 19.1 \\
& $\mathbf{1 4}$ & 19.7 & 19.9 & 20.3 & 20 \\
& $\mathbf{2 8}$ & 20.1 & 20.5 & 21 & 20.7 \\
Fat / DM \% & Fresh & 47.056 & 47.186 & 47.342 & 47.116 \\
& $\mathbf{1 4}$ & 47.666 & 47.955 & 48.197 & 48.004 \\
\hline
\end{tabular}

A: control cheese

B: Cheese with nisin $0.1 \mathrm{~g} / \mathrm{kgmilk}$

C: Cheese with nisin $0.2 \mathrm{~g} / \mathrm{kgmilk}$

D: Cheese with nisin $0.3 \mathrm{~g} / \mathrm{kgmilk}$ 
Table 2.The Total and Soluble nitrogen of Ricotta cheese during storage periods

\begin{tabular}{cccccc}
\hline Treatments & $\begin{array}{c}\text { Storage Period } \\
\text { (days }\end{array}$ & A & B & C & D \\
\hline \multirow{2}{*}{ TN } & Fresh & 2.248 & 2.276 & 2.329 & 2.298 \\
& $\mathbf{1 4}$ & 2.529 & 2.599 & 2.810 & 2.715 \\
& $\mathbf{2 8}$ & 2.642 & 2.726 & 3.091 & 2.810 \\
TN/DM & Fresh & 5.567 & 5.662 & 5.712 & 5.668 \\
& $\mathbf{1 4}$ & 6.119 & 6.263 & 6.671 & 6.316 \\
& $\mathbf{2 8}$ & 6.278 & 6.433 & 7.149 & 6.577 \\
SN & Fresh & 0.351 & 0.234 & 0.234 & 0.234 \\
& $\mathbf{1 4}$ & 0.585 & 0.468 & 0.168 & 0.351 \\
& $\mathbf{2 8}$ & 0.819 & 0.702 & 0.585 & 0.468 \\
\hline
\end{tabular}

The decrease in $\mathrm{pH}$ of control samples could be attributed to the bacterial multiplication.

The results indicated that T.S and S.N. of cheese increased during storage periods.

The total and soluble nitrogen of Ricotta cheese during storage periods was reported in Table (2). It was noticed that total nitrogen and soluble nitrogen increased during storage periods, soluble nitrogen increased from 0.351 to 0.819 in control samples while, soluble nitrogen increased from 0.234 to $0.702,0.234$ to 0.585 and 0.234 to 0.468 in samples treated with nisin respectively.

The slower protein break-down was evident in cheese treated with nisin compared with untreated samples of cheese. These results are in accordance with Leclercq-Perlat et al.(2002).

\section{Oragnoleptic properties of Ricotta cheese}

Table (3) showed that, the flavor and appearance scores of control sample decreased during storage periods, in case of nisin added samples flavor score remained within fair to good during storage periods. In case of nisin added samples overall acceptability scores remained within the acceptable limit until 28 days of storage. Samples with lower concentrations of nisin had better scores than the samples with higher concentrations in all cases. McSweeney and Fox (1993) reported that for most cheese varieties, proteolys used as index of maturity and it is thought that the breakdown of $\alpha$-casein is the most significant reaction responsible for softing of cheese body and texture indicating that textural changes during ripening are related to proteolysis.

\section{Rheology properties of Ricotta cheese}

Table (4) illustrate the rheological properties of ricotta cheese, It was important factors affecting cheese quality.
Protein, fat, and moisture were the three major constituents of cheese, which include more than $80 \%$ mass and directly affected textural and functional properties of cheese (Yates and Drake, 2007).

A reduction in hardness at 28 days of storage has been noticed in all cheese, the decrease in hardness after the 28 days of storage was related to decreasing moisture content which acts as a plasticizer in the protein matrix, thereby making it less elastic and more susceptible to fracture upon compression this agree with data obtained by (Fox et al., 2000).

Springiness reduced during 28 days of storage in all samples, it may be responsible for the release of calcium ions from mono-calcium and dicalcium Para K-casien molecules. These molecules has been reported to be responsible for the springiness of cheese curd (Kanawjia, et al., 1995).

\section{Microbiological analysis of Ricotta cheese}

Table (5) reveals average of total bacterial counts (TBC) of each treatment of Ricotta cheese samples. The results showed that TBC increased progressively during storage period at control samples from $21 * 10^{5}$ to $32 * 10^{5} \mathrm{cfu} / \mathrm{g}$, while TBC in Ricotta cheese with nisin was slower increasing during storage period from $21 * 10^{5}$ to $(31,27,26) * 10^{5} \mathrm{cfu} / \mathrm{g}$ in the different treatment respectively . proteolytic bacterial counts were increased gradually, while in Ricotta cheese with nisin proteolytic bacterial were slower increasing during storage periods.

Utilization of bacteriocin alone, or combined with other treatments, used for the microbiological safety and maintenance of sensory properties in milk and milk products (Lopez and Belloso 2008) . 
Table 3. Oragnoleptic properties of Ricotta cheese made with nisin during storage periods

\begin{tabular}{cccccc} 
Treatments & $\begin{array}{c}\text { Storage } \\
\text { Properties } \\
\text { Period } \\
\text { (days) }\end{array}$ & Flavor 10 & Body\&Texture 5 & Appearance 5 & Total 20 \\
\hline \multirow{2}{*}{ A } & Fresh & 7.2 & 4.2 & 4.1 & 15.5 \\
& $\mathbf{1 4}$ & 6.9 & 3.9 & 4.0 & 14.8 \\
B & $\mathbf{2 8}$ & 6.5 & 3.4 & 3.4 & 13.3 \\
& Fresh & 6.9 & 4.2 & 4.1 & 15.2 \\
& $\mathbf{1 4}$ & 7.0 & 4.0 & 4.1 & 15.1 \\
C & $\mathbf{2 8}$ & 6.8 & 4.0 & 3.2 & 14.0 \\
& Fresh & 7.8 & 3.9 & 3.6 & 15.3 \\
& $\mathbf{1 4}$ & 7.5 & 3.7 & 3.8 & 15.0 \\
D & $\mathbf{2 8}$ & 7.3 & 3.5 & 4.0 & 14.8 \\
& Fresh & 7.7 & 4.0 & 3.8 & 15.5 \\
& $\mathbf{1 4}$ & 7.7 & 3.9 & 3.6 & 15.2 \\
\hline
\end{tabular}

Table 4. Rheology properties of Ricotta cheese made with nisin during storage periods

\begin{tabular}{|c|c|c|c|c|c|}
\hline Rheology properties & $\begin{array}{l}\begin{array}{l}\text { Storage } \\
\text { periods }\end{array} \\
\end{array}$ & $\mathbf{A}$ & $\mathbf{B}$ & $\mathbf{C}$ & D \\
\hline \multirow[t]{3}{*}{ Hardness (g) } & Fresh & 160.7 & 169.9 & 160.2 & 169.8 \\
\hline & 28days & 135.3 & 146.2 & 149.8 & 155.7 \\
\hline & Fresh & 0.59 & 0.54 & 0.47 & 0.44 \\
\hline \multirow[t]{2}{*}{ Cohesiveness (g) } & 28days & 0.55 & 0.50 & 0.46 & 0.40 \\
\hline & Fresh & 8.84 & 8.11 & 8.15 & 8.04 \\
\hline \multirow{2}{*}{ Springiness (mm) } & 28days & 8.50 & 8.09 & 8.02 & 7.61 \\
\hline & Fresh & 18.34 & 18.97 & 19.80 & 19.45 \\
\hline \multirow[t]{2}{*}{ Gumminess (N) } & 28days & 14.22 & 15.11 & 18.00 & 18.86 \\
\hline & Fresh & 15.81 & 16.00 & 16.35 & 16.31 \\
\hline Chewiness (mJ) & 28days & 11.34 & 13.22 & 14.51 & 15.18 \\
\hline
\end{tabular}

Table 5. Microbiological analysis of Ricotta cheese made with nisin during storage periods

\begin{tabular}{cccccc}
\hline & Storage Period (days) & A & B & C & D \\
\hline Total count & $\mathbf{0}$ & 21.0 & 21.0 & 21.0 & 21.0 \\
$\left(\mathbf{1 0}^{\mathbf{5}} \mathbf{c f u} / \mathbf{g}\right)$ & $\mathbf{1 4}$ & 28.0 & 26.0 & 24.0 & 24.0 \\
& $\mathbf{2 8}$ & 32.0 & 31.0 & 27.0 & 26.0 \\
Pr.b & $\mathbf{0}$ & 7.0 & 7.0 & 7.0 & 7.0 \\
$\left(\mathbf{1 0}^{\mathbf{3}} \mathbf{c f u} / \mathbf{g}\right)$ & $\mathbf{1 4}$ & 18.0 & 10.0 & 9.0 & 7.0 \\
& $\mathbf{2 8}$ & 27.0 & 19.0 & 14.0 & 12.0 \\
\hline
\end{tabular}

The results indicated that, acidity and microorganism count increased in all treatments during storage, whereas $\mathrm{pH}$ decreased. Similar results were reported by Olmedo et al. (2013).

\section{CONCLUSION}

Using anti-microbial nisin was studied to increase the self life of Ricotta cheese. The results illustrated that adding nisin ( 0.2 and $0.3 \mathrm{mg} \backslash \mathrm{Kg}$ milk) increased the self life of Ricotta cheese to 28 days, so the research recommended that using nisin as natural food preservation.

\section{REFERENCES}

AOAC.1991. Association of Official Analytical Chemists. Official Methods of Analysis Washington DC.

APHA .1992. American Puplic Health Association. Standard methods for the examination of dairy products - American Puplic Health Association Inc. $12^{\text {th }}$ Ed, New York. 
Bodyfelt, F.W., D. Potter .2009. The Sensory Evaluation of Dairy Products, $2^{\text {nd }}$ ed . Springer, New York. NY.pp:167190.

Bourne, M. 1978. Texture Profile Analysis. Food Tech. 32: 62-72.

Campbell-Platt, G. 1987.Fermented Foods of the World- A Dictionary and Guide. London : Butterworths.

Dal Bello, B., L. Cocolin, G. Zeppa, D.Field, P. D. Cotter and C. Hill.2012.Technological characterization of bacterocin producing lactococcus lactis strains employed to control listeria monocytogenes in cottage cheese. International Journal of Food Microbiology.1531(12):58-65.

Delves-Broughton, J. 1990. Nisin and its uses as a food preservative. Food Technology 44:100- 102-104-106108- 111-112- 117.

Fox, P.E. T. P. Guinee, T .M. Cogen . and P.L.H. Mcsweeney .2000. Fundmentals of cheese science .Aspen Publish ers.Gaithersburg .MD. Guinee, T. P. 2002. Cheese Rheology: 341-349.

Hwanhlem,N., V. Biscola, S. El-Ghaish, E. Jaffres, X. Dousset,T.Haertl, A. Kittikun and J.M. Chobert.2013. Bacteriocin-producing lactic acid bacteria isolated from mangrove for- ests in southern Thailand as potential biocontrol agents: Purification and characterization of bacteriocin produced by Lactococcus lactis subsp. Lactis KT2W2L. Probiotics and Antimicrobial Proteins, 5(4): $264-278$.

Jeevaratnam, K. M. Jamuna and A. S. Bawa. 2005. Indian Journal of Biotechnology 4.pp. :446-454.

Kanawjia, S. K., P. Rajesh, L. Sabikhi, and S. Singh. 1995. Flavor, chemical and texture profile changes in accelerated ripened Gouda cheese. Lebensm. Wiss. Technol. 28:577583.
Klaenhammer, T.R. 1993. FEMS Microbiol Rev. 12: 3985.Leclercq-Perlat, M. N., A.Oumer, J. L.Bergere.

Spinnler H. E. and G. Corrieu. 2002. Behavior of Brevibacterium linens and Debaryomyces hansenii as ripening flora in controlled production of smear soft cheese from reconstituted milk: growth and substrate consumption. J. Dairy Sci. 83: 1665.

Ledenbach. L.H., R. T.Marshall.2009. Microbiological spoilage of dairy products In: Sperber, W.H., Doyle, M.P. (Eds.). Compendium of the microbiological spoilage of Foods and Beverages, Food Microbiology and Food Safety, Springer Science + Business Media B.V. Dordrecht, Netherlands.

Lopez,A. and O. Belloso. 2008.Use of nisin and other bacteriocins for preservation of dairy products. International Dairy J. 18 (4) :329-343.

McSweeney, P.L.H. and P.F. Fox.1993. Cheese: methods of Chemistry, Physics and Microbiology. Vol. 1: General Aspects. $2^{\text {nd }}$ Ed., Edited by Fox, P. F., Chapman and Hall, London.

Mucchetti, G., D. Carminati and A.Pirisi. 2002. Ricotta fresca vaccinaed ovina: osservazioni sulle tecniche di produzione e sulprodotto. Il Latte 27:154-166.

Modler, H.W. 1988. Journal of dairy science. 71 (8) : 20032009.

Olmedo, R.H., V. Nepote and N.R. Grosso. 2013. Preservation of sensory and chemical properties in flavoured cheese prepared with cream cheese base using oregano and rosemary essential oils. LWT - Food Science and Technology.53:409-417.

Postollec, F., A. C.Mathot, M. Bernard, M.L.Divanach, S.Pavan and D. Sohier. 2012.Traking spore forming bacteria in food: from natural biodiversity to selection by processes. Int. J. Food Microbial. 158 (1): 1-8.

Yates M. D. and M. A. Drake.2007. Texture properties of gouda cheese, Journal of Sensory Studies, vol. 22, no. 5, pp. 493-506. View at Publisher. View at Google Scholar . View at Scopus. 


\section{الملخص العربي \\ تاثير استخدام bacteriocin علي الجبن الطرى}

$$
\text { سلفيا مجدي زكي - وفاء احمد محمود }
$$

فقد حصل على درجات تحكيم اعلى من الجبن الغير معامل

r-اوضحت النتائج المتحصل عليها ان اضافة النيسين ادى الى تحسين الصفات الريولوجيه للجبن المعامل عن

$$
\text { الكنتزول }
$$

؟-لوحظ ان العد الميكروبى فى الجبن الريكوتا المعامله بالنيسين اقل بالمقارنه بعينة الكنترول خلال فترة تخزين الجبن

توصى الدراسه باضافة نسبة 0.2 , 0.3 نيسين لزيادة مدة حفظ جبن الريكوتا الى ^^ يوما حيث يعتبر النيسين

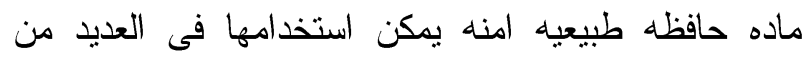
انواع الاطعده المختلفه خصوصـا انو اع الجبن الطري.
استهدفت الدر اسه تقييم فاعلية استخدام bacteriocin فى صناعة احد انواع الجبن الطرى وهو جبن الريكوتا باستخدام نسب اضافه مختلفه على اللبن حيث استخدمت نسب اضافه 0.1 - 0.2 - 0.3 جم من النيسين / كجم لبن جاموسى وتم تصنيع الجبن و التخزين لمدة ^^ يوم • ولقد اظهرت النتائج مايلى : 1-اضافة النيسين ادت الى حدوث انخفاض فى الحموضه وزيادة pH و انخفاض الرطوبه خلا فترة التخزين بالمقارنه بالجبن الغير معامل بالنيسين (الكنتزول). r-اضافة النيسين اعطى للجبن افضل صفات حسيه بصفة عامه اما الجبن المضاف اليه نسبة 0.2 و 0.3 جم نيسين 